\title{
Review on Multi-Objectives Optimization Methods in Hybrid Power Generation
}

\author{
Syafaruddin \\ Department of Electrical Engineering, Universitas Hasanuddin, Jalan Poros Malino Km. 6, Gowa 92171, Indonesia
}

Received 8 January 2019; Accepted 20 February 2019

\begin{abstract}
One of the popular topics in hybrid power generation is how to optimize the operation and performance of systems considering the behavior of different input variabilities and characteristics of power generation including customers load fluctuation. In optimization problems, several objective functions within certain constraints have been reviewed, for instance to minimize the gas carbon emission, to reduce the fuel cost consumption for power generation, to maximize the capacity of renewable energy sources in hybrid power generation and so on. To achieve the solution for the optimization problems, several computational methods and techniques based on mathematical numeric approaches, artificial computational techniques and meta-heuristic techniques have been proposed. This paper would like to investigate more detailed about the multi-objectives optimization techniques in hybrid power generation for the reasons of popularity of techniques in recent years. In future, the fast and accurate computational capabilities with simple algorithms are expecting to play important role for the solution of multi-objective optimization tasks in hybrid power generation.
\end{abstract}

Keywords: Multi-objectives optimization, hybrid power generation, conventional computational method, intelligent techniques, metaheuristic approaches.

\section{Introduction}

The power generation based renewable energy sources are the prominent solution for increasing energy demand, energy shortage and environmental issues. The electricity demand is well known triggered by the escalating of population and economic activity growth. Increase the activities in socioeconomy has emergence the need of energy. The rapid growth in energy demand has triggered the increase in greenhouse gas emission to atmosphere and potentials rise in fuel price. These were the motivation of renewable energy utilization. However, the renewable energy sources have certain drawbacks, such as fluctuated output generation and highly depending on the environmental climate conditions. Therefor the combination with conventional power generation in hybrid forms is recommended. To maximize the benefits of hybrid systems, a complex design, planning and control optimization method is required [1]. Significance of renewable technology in hybrids systems have been reviewed with the focus on energy shortage and future sustainability. The review covers the potential of sources, structure design including the power electronics involved, energy management and the future vision of integrated power generation [2].

Several reasons why the paradigm of hybrid power generation is increasing nowadays. The increase in electricity energy demand and the price of fossil fuels could be the prominent reasons, especially to the industrial load and the existence of electricity market where the price is volatile. Therefore, the hybrid power generation systems may solve the price market instability regarding the energy provision to industrial load through the optimization of uncertainty pool

*E-mail address: syafaruddin@unhas.ac.id

ISSN: $1791-2377$ @ 2019 Eastern Macedonia and Thrace Institute of Technology. All rights reserved. doi:10.25103/iestr.121.17 rate [3]. In order to support the development of hybrid systems, an innovative optimization based assessment tool of hybrid power generation for optimum configuration is importantly designed. The performance index is designed based the double-step performance based economic and environmental assessment within the influences of governmental regulation and social impacts [4]. In this respect, the economic assessment includes cost of electricity, energy excess percentage, and operating life cycle indicators. Meanwhile, the environmental assessment covers the renewable contribution, renewable source availability and environmental impact indicators.

Increase in electricity demand due to the world population and economic growth. Renewable energy comes to solve the potentials of energy crisis and to avoid environmental degradation. However, the energy needs from renewable energy is limited by the stochastic nature of energy sources and technical-economical optimization problems. This limitation can be minimized by the combinational operation with conventional generation systems in the form of hybrid operation [5]. The hybrid power generation is always overlooked by the efficiency and techno-economic feasibility [6]. The energy and distribution management systems provide control for the hybrid energy sources including the prediction of sources utilization. The prediction and estimation in hybrid power generation could be from the views of resource potential, technology, efficiency and load patterns. This approach is taken to have optimal utilization of renewable energy sources in hybrid power generation in terms of technical and economic feasibility. In addition, hybrid power generation is the solution for the increasing in global energy consumption, while the conventional energy sources facing the limitation of energy supply [7]. However, operation the renewable energy supply is unreliable and unstable with the output energy fluctuation. The hybrid energy systems are commonly reviewed for the perspectives of challenges and 
utilization, stability improvement in energy supply and optimization strategy to minimize the operational cost and carbon gas reduction.

Optimization tasks are highly important to expect the competitions of hybrid power generation to single conventional power generation system. The operation hybrid system is rather complex, that is way the management strategy framework for the operation can be approached by a rolling time horizon philosophy [8]. The hybrid power generation system design is complex because it needs to deal with high number of parameters [9]. The optimal configuration should not depend on only specific performance index. Otherwise, it leads to the misoperation and incorrect configuration. The sizing and optimal performance of hybrid system should be measured with powerful performance index that covers loss of power probability, energy excess percentage and cost of energy. Therefore, the hybrid system is another important option for power generation regarding the technical, economic and environmental benefits. The optimal scheduling strategy of different power generation is implemented for the economic and environmental benefits within the technical limitation [10].

As an example, solar and wind energy are the most potential renewable energy sources that can be integrated to supply the electricity of remote area. The sources can be found freely and have less impact to the environment. The most common challenge of the hybrid solar and wind power system is to find the technical and economic benefits in the form of optimal systems in terms of maximum sizing and minimum operational cost. In addition, optimization problems may consider the compromise solution between the hybrid system reliability and system costs [11]. The optimization method of PV wind hybrid power generation for optimal size and location is presented taking into account deficiency of power supply probability, relative excess power generated, unutilized energy probability, life cycle cost, level of energy cost and life cycle unit cost of overall systems with energy storage [12].

The optimal techno-economic stand-alone hybrid power generation based photovoltaic system, fuel cell and battery systems is developed to meet the daily load demand. The investigation is focused on the reliability loss power index, economic sizing based cost of energy [13]. The optimum system configuration is obtained with finding the trade-off between investment cost and power reliability. The approach is very similar to the hybrid systems configuration of photovoltaic system, methanol fuel cell (MFC) and electricity storage systems to meet daily load demand. The optimization algorithm solves the optimal performance on main power generator, charging and discharging battery systems, hybrid power management strategy and economic power dispatch [14]. Under stochastic operational condition, the optimal design and operation of hybrid systems with hydrogen storage can be achieved with development power management for different ways of power dispatch [15]. In this respect, the optimization method is deployed to find the optimal parameters affect the system performance.

Indeed, Due to the hybrid power generation system is composed from different type of energy sources, it is difficult to obtain the optimal configuration, optimal location, optimal operational cost and other multi objectives. Therefore, the optimization technique is deployed to solve such kind of problems. The main point of optimized hybrid power generation is how to reduce the operational cost and increase the power generation. The topic has been intensively reviewed according the optimization method and algorithm including the tool for renewable energy optimization [16], [17]. This paper attempts to provide clear information regarding the optimization techniques to increase and to maximize the hybrid power generation systems paradigm that has been proposed in scientific literature. It is important approach in order to support the research and development of hybrid power generation system for the future fulfilment energy demand. More detail information regarding the optimization techniques and other aspects of hybrid power generation are provided in the following section.

\section{Numerical Methods}

The conventional methods for solving the optimization problems in hybrid power generation are still attracted by some researchers (Table 1). The approach to find the solution of problems is basically following the mathematical model solving with numerical method and analysis with sometimes come up with statistical assumption. For instance, the mathematical model of hybrid power system based wind power and pump hydro storage including diesel generator that supplies remote area is presented. The formulated model is solved by the mixed-integer linear program for the optimization problems include the minimization of diesel fuel consumption and to determine the optimal number of wind turbines, size of the upper water reservoir, and charge/discharge rates of the pump hydro storage system [18]. Similar method is utilized for optimal scheduling is performed with solution based mixed-integer linear programming to increase the generation plan and reduce the wind speed curtailment in hybrid power based concentrated solar thermal with heat storage and electric heater and wind power [19]. With this method, the hybrid systems may improve the flexibility of operational scheduling in the case of wind power connection due to the low wind speed conditions.

The integration of power generation systems that utilizes net energy concept consider technical, economical, socio as well as environmental aspects. The paper presents the integrated analytical hierarchy process for the optimal design of hybrid power generation. The conventional optimization is used to minimize the cost, while the analytical hierarchy process is performed for decision making problems [20]. It is obtained that the technical-economy aspects depend on the quantitative parameters, while socio-environment depends on the criteria of system planning and future system utilization. However, the optimal design configuration of hybrid power system connected to the grid depend on several aspects, such as uncertainty of socio-economic and environmental variables, technical problems and government attentions. These aspects are not easy tasks. Therefore, the optimization technique based on Multi Criteria Decision Analysis (MCDA) is presented with the optimization target of reduction of gas emission, total cost and social satisfactory [21]. The research is supported by several analyses, such as uncertainty, probability and sensitivity for different parameters.

One reason of increasing the hybrid power generation is to anticipate the global climate changes and to solve the future energy shortage. New paradigm of clean energy natural gas and renewable energy is proposed to investigate the combination operation scenarios are more attractive in some cases. It is due to the solar and wind energy have intermittent output and somewhat unreliable to generate electricity independently, also the natural gas price is sometimes unsta- 
ble. The important target of this research is to balancing the power generation in terms of reliability and flexibility and dispatch-ability obtained through comparative analysis based combination of data analysis system and paradigm theory [22]. As results, the hybrid system with abundance source of wind and solar energy may improve the system efficiency and reduce the carbon emission and other pollutants. Meanwhile, for the cost-effective sizing of battery including the capacity of biomass systems integrated in distributed power generation, the sensitivity analysis can be taken based realistic load profile [23].

Table 1. Summary of numerical methods

\begin{tabular}{|c|c|c|c|}
\hline Hybrid Models & Numerical Methods & Optimization Tasks & Refs. \\
\hline Wind-pumped-storage & \multirow[t]{2}{*}{$\begin{array}{l}\text { Mixed-integer linear pro- } \\
\text { gram }\end{array}$} & $\begin{array}{l}\text { Minimization of diesel fuel consumption and de- } \\
\text { termine optimal number of wind turbines, size of } \\
\text { the upper water reservoir, and charge/discharge } \\
\text { rates of the pump hydro storage system }\end{array}$ & {$[18]$} \\
\hline $\begin{array}{l}\text { Wind-concentrated solar } \\
\text { power }\end{array}$ & & $\begin{array}{l}\text { Optimal scheduling to increase generation plan } \\
\text { and reduce the wind speed curtailment }\end{array}$ & [19] \\
\hline $\begin{array}{l}\text { Diesel-hybrid power } \\
\text { generations }\end{array}$ & Analytical hierarchy process & Decision making problems & {$[20]$} \\
\hline $\begin{array}{l}\text { Photovoltaic system- } \\
\text { wind turbine }\end{array}$ & $\begin{array}{l}\text { Multi criteria decision analy- } \\
\text { sis }\end{array}$ & $\begin{array}{l}\text { of gas emission, total cost and social } \\
y\end{array}$ & {$[21]$} \\
\hline $\begin{array}{l}\text { Wind and solar power } \\
\text { with natural gas }\end{array}$ & $\begin{array}{l}\text { Combination of data analysis } \\
\text { system and paradigm theory }\end{array}$ & $\begin{array}{l}\text { Balancing the power generation in terms of relia- } \\
\text { bility and flexibility and dispatch-ability }\end{array}$ & {$[22]$} \\
\hline $\begin{array}{l}\text { Biomass gasifier, solar } \\
\text { PV and battery system }\end{array}$ & Sensitivity analysis & $\begin{array}{l}\text { Cost-effective sizing of battery and capacity of } \\
\text { biomass systems }\end{array}$ & {$[23]$} \\
\hline $\begin{array}{l}\text { Hybrid solar energy } \\
\text { based beta-type Stirling } \\
\text { engine }\end{array}$ & $\begin{array}{l}\text { Generic non-linear identifi- } \\
\text { cation based knowledge } \\
\text { model }\end{array}$ & $\begin{array}{l}\text { Evaluation of dynamics parameters of thermody- } \\
\text { namic process of thermal engines }\end{array}$ & {$[24]$} \\
\hline $\begin{array}{l}\text { Photovoltaic-fuel cell } \\
\text { (PVFC) systems with } \\
\text { battery systems }\end{array}$ & $\begin{array}{l}\text { Generic mathematical pro- } \\
\text { gramming model based tem- } \\
\text { poral flexibility index }\end{array}$ & $\begin{array}{l}\text { Optimal performance of photovoltaic system and } \\
\text { fuel cell in realistic environment and uncertain } \\
\text { disturbance }\end{array}$ & {$[25]$} \\
\hline $\begin{array}{l}\text { Diesel system - renewa- } \\
\text { ble energy sources }\end{array}$ & $\begin{array}{l}\text { Sparse matrices and linear } \\
\text { programming algorithms }\end{array}$ & Optimal design capacity and operation planning & {$[26]$} \\
\hline
\end{tabular}

The thermodynamic engines become important aspects in the increasing utilization of solar based electric power generation. In this work, the scheme of generic non-linear identification based knowledge model can be used to evaluate the dynamics parameters of thermodynamic process of thermal engines [24]. The proposed model is generally suitable for simulation and control design of power generation with thermal engine. Similar approach with generic mathematical programming model based temporal flexibility index is utilized for the hybrid generation process [25]. In this case, the performance of photovoltaic system and fuel cell in realistic environment and uncertain disturbance taking the fluctuation of energy supply and demand is evaluated. Meanwhile, the optimization method to match the hourly supply and demand for one-year operation of hybrid power generation is investigated for the optimal design capacity and operation planning. Because the number of data is overloaded, the sparse matrices and linear programming algorithms with linear constraints are introduced to reduce the computational time [26].

\section{Intelligent Techniques}

There are so many previous research of optimization techniques of sizing and design the hybrid power generation in scientific literature. Mostly the previous research methods proposed the intelligent techniques algorithm, since they require less computational time and effort, fast convergence and offer low error performance compared to the conventional optimization techniques [27]. The intelligent system method for the optimal operation of hybrid systems is commonly presented in order to improve the efficiency output of renewable energy. An extensive example of intelligent techniques over other numerical techniques is the optimal sizing of hybrid power generation with the objective function to minimize the operational cost to meet the load demand of isolated area. The solution is determined with swarm intelligent technique called grey wolf optimizer which follows the leadership hierarchy and hunting mechanism in finding the optimal condition [28]. The proposed method is fast convergence, lower cost and superior capability than that of in other intelligent methods. The summary of intelligent techniques for solving the optimization problems is provided in Table 2.

\subsection{Neural Network}

Amongst the intelligent techniques, the artificial neural network is one of the most popular methods of solving the optimization problems in hybrid power generations. In this case, artificial neural network has been widely used in the area modeling, simulation and control of renewable energy systems due to the easy implementation [29]. The artificial intelligence method is used for practical design and dynamic based intelligent control strategy for the automatic hybrid system performance to meet the power demand of single remote housing application [30]. The optimum configuration of hybrid systems is achieved with extensive data prediction using artificial neural network and validated with root mean square error method [31]. It is due to the hybrid combination of hydro power with wind and solar energy might solve the hydro problems regarding the limited social and environmental aspects, especially when the water flow rate decreases during specific period.

In terms of utilization of artificial neural network for intelligent control, the real power control is proposed as the control systems for hybrid power generation. The proposed method includes the application of radial basis function (RBF) neural network to track the optimum power of solar 
array and improve Elman neural network (ENN) to determine the pitch angle control of wind power [32]. The proposed method is simulated with dynamic simulation based Matlab software environment. In addition, the adaptive neural network model based back propagation algorithm is implemented as the supervisory controller for hybrid PV micro-grid systems [33]. In this case, the input-output data training is taken from the non-linear model behavior of hybrid system in order to achieve the optimal performance and high accuracy.

\subsection{Evolutionary Computing}

The evolutionary computing techniques are also attracted much attention in solving the non-linearity characteristic of hybrid power generation. The intelligent algorithm and automatic operation for optimal management of hybrid systems is presented taking into account genetic algorithms combined with fuzzy logic system [34]. More specifically, the hybrid intelligent computational approaches may overcome the limitation and burden on single method. These algorithms are utilized for the optimal connection energy storage device and energy sources connected to the grid to meet the load demand. In other cases, the dynamic behavior and simulation of stand-alone hybrid power generation is presented taking the genetic algorithm for economic analysis [35]. The other methods of Lyapunov model with feedback linearization is used to obtain the maximum energy of wind power. Then, a fuzzy logic controller compared with the adaptive control is applied for the overall system performance to supply load demand. In addition, a supervisory control is implemented for the maximum energy capture and energy consumption for the whole system performance.

The multi-objective optimization is the main consideration to obtain the optimal performance of hybrid power generation. In this case, the hybrid systems based fuel cell and gas turbine is modeled and analyzed from thermal, economic and environmental perspectives. The genetic algorithm is utilized as the multi objective optimization to determine the optimal parameters of system design taking the objective functions of exergy efficiency, total costs rate of the system and social cost of air pollution [36]. Also, the sensitivity analysis is deployed to investigate the effects of fuel cost fluctuation in the Pareto optimal solutions and corresponding parameters. The optimum design in the perspectives of different economic and environmental performance of hybrid power generation based solar and wind energy is presented with Non-Dominated Sorting Genetic Algorithm to provide decision support mechanism to solve the multiobjective problems [37]. The multi-objective optimization task are the minimum system total cost and maximum reliability, while the uncertainty problems is solved by the innovative method called Chance Constrained Programming (CCP) and validated by Monte Carlo simulation.

The dynamic modeling, simulation, control and energy management system of stand-alone hybrid power generation is presented with genetic algorithm to obtain the efficient and economical operation of renewable energy source, optimal capacity of hybrid systems based on economic analysis [38]. The power consumption model of micro-turbine considers the least square estimation algorithm for economic analysis, while the maximum energy extraction from wind power utilizes the Lyapunov model with adaptive feedback linearization and indirect space vector control. In addition, a supervisory controller is designed for energy management between the maximum energy captured from the wind turbine and consumed energies of the load, dump load, energy of the battery based on state of charge and generated energy by the micro-turbine. The GA algorithm has been used to optimize the performance of standalone hybrid power generation based combined heat and power generation [39]. The objective of this study is to analyze the system cost and performance to meet both electric and heating loads. In addition, the energy management system for hybrid power generation based wind-solar and bioethanol for fuel cell systems is presented. The optimal sizing of stand-alone hybrid system is calculated with genetic algorithm under different load according historical climate conditions [40].

\subsection{Swarm Intelligence}

The solving of multi-objective optimization problems in hybrid power generation by the swarm intelligence approaches is getting popular in recent years. It is due to the hybrid systems with renewable energy may support the fulfillment capacity of energy demand due to the increasing in energy demand. The optimal performance improvement of stand-alone hybrid power systems connected to distribution systems with the objective function of the minimum total losses, voltage deviation including gas emission and maximum energy index are investigated. Also, the reduction in terms of combined cost and emissions after energy purchased from the grid and the energy generated by distributed generation units is obtained utilizing Multi-Objective Particle Swarm Optimization (MOPSO) algorithm within the contradicting objectives [41]. Similarly, the optimal sizing of stand-alone hybrid power generation of photovoltaic systems, wind energy and battery system with both single and multiple objectives optimization technique is solved based on GA-PSO and MOPSO, respectively [41]. The target of this study is to find the minimum costs of initial instalment, operation and maintenance and replacement systems within the fulfilment of load demand. The results with HOMER software is also used to validate the results from these two methods.

Multi-objective optimization problems are commonly with the objective functions of operating costs, efficiency and lifetime of the devices which can be simplified into single objective function by the energy management system approaches. In this case, the energy management for optimum operation of hybrid grid connected systems of photovoltaic system, wind power with battery and hydrogen systems are solved with PSO method [43]. The combination between the PSO and GA algorithms is used for the multiobjective optimization hybrid power generation performance based solar thermal heliostat field and gas turbine [44]. Meanwhile, the combination between game theory and PSO algorithm have been used to increase the use of renewable energy source and improve the energy efficiency on both supply and demand within the tight competition on both price and quantity of electricity energy sector. The provision of decision support tools for long term strategic plan within dynamic operational condition may be useful for planning approach and strategic efficiency [45].

Multi-agent based energy coordination control system for grid connected hybrid power systems is designed to solve the challenges of low operation efficiency, poor stability, and complex decision making. The optimal energy distribution is solved with PSO algorithm taking into account of self-constraints and control objective for the global energy optimization [46]. For the application of robust control, the PSO algorithm is used for tracking the global maximum point of photovoltaic systems and new algorithm is developed as supervisory control to determine the set point con- 
trol [47]. The optimal set point is highest voltage and lower current that provide the same power output. Therefore, the optimization performance of control technique is utilized for the target of high accuracy and reducing power loses.

The power generation with renewable energy sources is considered as the promising solution for the environmental and energy shortage issues. The hybrid power generation offers the solution of climate change obstacles, permit better reliability, and reduction of cost energy. The optimal sizing of hybrid power generation is the common consideration for the optimal operation condition. In this case, the PSO algorithm for optimal design and sizing within the minimum cost of generated energy and particular reliability index [48]. Similarly, the optimal design of hybrid power generation is proposed with PSO algorithm to minimize the total system cost, reliability index based loss of load probability and carbon emission [49]. The results of proposed method are compared with the HOMER software in terms of cost reduction during disconnected and unmet load conditions, and the yearly cost of diesel generator.

The review of hybrid power generation is presented in terms of configuration, control strategy, techno-economic analysis and social effect in order to provide comprehensive understanding in hybrid design and control in the real system practice. With using the homer software and PSO algorithm, it reveals that hybrid system has the most logical solution for optimal COE, renewable fraction, maximum renewable penetration, levelized cost, operating cost, mean electrical efficiency, and emission reduction [50]. Meanwhile, the transient performance of hybrid system integrated with thermal unit is investigated with optimized parameters by a novel craziness-based PSO with wavelet mutation for the optimal and robust control performance [51].

The management of hybrid power systems is investigated from different optimization techniques for load sharing contributing from available generating systems within specified constraints. The optimization techniques are Imperialist Competitive Algorithm (ICA), Particle Swarm Optimization (PSO), Quantum behaved Particle Swarm Optimization (QPSO), Ant Colony Optimization (ACO), and Cuckoo Optimization Algorithm (COA) [52]. To achieve the optimal performance, the control strategy is deployed for the ratio of energy production over energy consumption. The economic feasibility of hybrid power generation is investigated with the targets of net present cost, levelized cost of energy, amount of carbon gas emissions, and the fulfilment of load demand at different environmental conditions. The multiobjective optimization is performed with ACO algorithm to reduce cost, emissions, and a combined solution between cost and emissions in different fuel options [53]. The method is compared with GA, PSO and HOMER software.

\subsection{Fuzzy Systems}

The fuzzy logic systems are commonly implemented to find the optimal control solution in hybrid power generation. For instances in hybrid fuel cell and battery system, different layers of control strategy for active power flow is presented using on-line power management by a hierarchical hybrid controller. In this case, the supervisory control to capture all possible operation modes and advance fuzzy control for power splitting switch between power generations [54]. Then, local controller is implemented to obtain the best performance within acceptable operation index. In other approaches, the hybrid systems based fuel cell and battery is potentially to increase the energy conversion efficiency and the dynamic system response. The fuzzy logic algorithm is used to obtain the fuel cell output according to the external power requirement and status of battery operation. For this purpose, the if-then rules of fuzzy logic system is utilized for the energy management control of hybrid systems [55].

The optimization of hybrid power generation based solar and wind energy is presented to minimize the annual cost to satisfy the reliability constraints. The high resolution model based fuzzy inference systems is used to evaluate the active components and domestic energy consumption [56]. The reliability constraint called seasonal loss of load probability ratio is introduced to obtain the accurate sizing of hybrid systems. Meanwhile, the optimal location for the hybrid wind and solar energy is discussed in terms of economic, social, geological and natural disaster criteria. Data and hybrid rank utilization is analyzed with fuzzy system methods [57].

Table 2. Summary of Artificial Intelligence Methods

\begin{tabular}{|c|c|c|c|c|}
\hline Hybrid Models & $\begin{array}{l}\text { Intelligent Meth- } \\
\text { ods }\end{array}$ & Variants & Tasks & Refs. \\
\hline $\begin{array}{l}\text { PV systems-wind } \\
\text { energy }\end{array}$ & \multirow{4}{*}{ Neural Network } & \multirow[b]{2}{*}{ Artificial neural network } & Modeling, simulation and control & {$[29]$} \\
\hline $\begin{array}{l}\text { Photovoltaic- } \\
\text { micro wind sys- } \\
\text { tems }\end{array}$ & & & Optimum configuration & {$[31]$} \\
\hline $\begin{array}{l}\text { Solar-wind power } \\
\& \text { diesel-engine }\end{array}$ & & RBF \& Elman network & Real power control & {$[32]$} \\
\hline $\begin{array}{l}\text { PV-microgrid } \\
\text { systems }\end{array}$ & & Adaptive neural network & Supervisory controller & {$[33]$} \\
\hline $\begin{array}{l}\text { Wind turbine- } \\
\text { photovoltaic pan- } \\
\text { els \& battery } \\
\text { bank }\end{array}$ & \multirow{4}{*}{$\begin{array}{l}\text { Evolutionary Com- } \\
\text { puting }\end{array}$} & $\begin{array}{l}\text { Genetic algorithm with } \\
\text { fuzzy logic systems }\end{array}$ & $\begin{array}{l}\text { Optimal connection energy storage de- } \\
\text { vice and energy sources }\end{array}$ & {$[34]$} \\
\hline $\begin{array}{l}\text { Wind turbine, } \\
\text { microturbine, } \\
\text { solar array \& } \\
\text { battery storage }\end{array}$ & & $\begin{array}{l}\text { Genetic algorithm with } \\
\text { Lyapunov model }\end{array}$ & Economic analysis & {$[35]$} \\
\hline $\begin{array}{l}\text { Wind turbine, PV } \\
\text { panel \& battery } \\
\text { bank }\end{array}$ & & $\begin{array}{l}\text { Non-dominated Sorting } \\
\text { genetic algorithm }\end{array}$ & Multi-objective parameters optimization & {$[37]$} \\
\hline Solid oxide fuel & & Genetic algorithm & Multi-objective parameters optimization & [36] \\
\hline
\end{tabular}




\begin{tabular}{|c|c|c|c|c|}
\hline cell-gas turbine & & & & \\
\hline $\begin{array}{l}\text { Offshore wind } \\
\text { turbine, tidal tur- } \\
\text { bine, micro- } \\
\text { turbine \& lead } \\
\text { acid battery stor- } \\
\text { age }\end{array}$ & & & $\begin{array}{l}\text { Efficient and economical operation of } \\
\text { renewable energy source and optimal } \\
\text { capacity }\end{array}$ & {$[38]$} \\
\hline $\begin{array}{l}\text { PV-combustion } \\
\text { engines }\end{array}$ & & & Optimal performance & [39] \\
\hline $\begin{array}{l}\text { Wind-solar ener- } \\
\text { gy and bioethanol } \\
\text { fuel cell systems }\end{array}$ & & & Optimal sizing & [40] \\
\hline $\begin{array}{l}\text { Photovoltaic pan- } \\
\text { els, wind turbine } \\
\text { generators, batter- } \\
\text { ies \& diesel gen- } \\
\text { erator }\end{array}$ & \multirow{12}{*}{ Swarm Intelligence } & $\begin{array}{l}\text { Multi-Objective Particle } \\
\text { Swarm Optimization } \\
\text { (MOPSO) }\end{array}$ & Optimal performance & {$[41]$} \\
\hline $\begin{array}{l}\text { Photovoltaic pan- } \\
\text { els, wind tur- } \\
\text { bines, and battery }\end{array}$ & & $\begin{array}{l}\text { Multi-Objective Particle } \\
\text { Swarm Optimization } \\
\text { (MOPSO) }\end{array}$ & Minimum cost & {$[42]$} \\
\hline $\begin{array}{l}\text { Solar energy \& } \\
\text { combustion gas } \\
\text { turbine cycle }\end{array}$ & & PSO and GA & Optimal performance & {$[44]$} \\
\hline \multirow[t]{2}{*}{$\begin{array}{l}\text { Hybrid renewable } \\
\text { energy sources }\end{array}$} & & PSO and game theory & $\begin{array}{l}\text { decision support tools for long term } \\
\text { strategic plan }\end{array}$ & {$[45]$} \\
\hline & & PSO and HOMER software & Optimal configuration & [50] \\
\hline $\begin{array}{l}\text { Thermal power } \\
\text { plant, wind tur- } \\
\text { bine generators, } \\
\text { aqua electrolyzer, } \\
\text { fuel cells, diesel } \\
\text { engine generator, } \\
\text { flywheel energy } \\
\text { storage system \& } \\
\text { battery energy } \\
\text { storage system }\end{array}$ & & PSO with wavelet mutation & Optimal and robust control performance & [51] \\
\hline $\begin{array}{l}\text { Wind turbine and } \\
\text { photovoltaic with } \\
\text { battery \& fuel cell } \\
\text { and electrolyzer. }\end{array}$ & & \multirow{5}{*}{$\mathrm{PSO}$} & $\begin{array}{l}\text { Optimal operation of grid hybrid power } \\
\text { generation }\end{array}$ & {$[43]$} \\
\hline $\begin{array}{l}\text { Photovoltaic- } \\
\text { wind energy sys- } \\
\text { tems }\end{array}$ & & & optimal design and sizing & {$[48]$} \\
\hline $\begin{array}{l}\text { PV panel, diesel } \\
\text { generator \& bat- } \\
\text { tery banks }\end{array}$ & & & Minimum total cost & [49] \\
\hline $\begin{array}{l}\text { Wind- } \\
\text { photovoltaic en- } \\
\text { ergy storage } \\
\text { power }\end{array}$ & & & Optimal energy distribution & {$[46]$} \\
\hline $\begin{array}{l}\text { PV systems as a } \\
\text { part of hybrid } \\
\text { power generation }\end{array}$ & & & Supervisory control & {$[47]$} \\
\hline $\begin{array}{l}\text { Hybrid microgrid } \\
\text { systems }\end{array}$ & & $\mathrm{ACO}$ & Minimum cost and emission & {$[53]$} \\
\hline $\begin{array}{l}\text { Battery bank and } \\
\text { a solid oxide fuel } \\
\text { cell }\end{array}$ & \multirow{5}{*}{ Fuzzy systems } & Fuzzy control system & Supervisory control & {$[54]$} \\
\hline $\begin{array}{l}\text { Fuel cells and } \\
\text { batteries systems }\end{array}$ & & Fuzzy logic system & Energy management control & {$[55]$} \\
\hline $\begin{array}{l}\text { Photovoltaic- } \\
\text { wind turbine- } \\
\text { battery banks }\end{array}$ & & Fuzzy inference system & $\begin{array}{l}\text { Evaluation of active components and } \\
\text { domestic energy consumption }\end{array}$ & {$[56]$} \\
\hline Wind-solar plant & & Fuzzy system & Optimal location & {$[57]$} \\
\hline Photovoltaic, fuel & & Fuzzy Sliding control & Sharing power flow control & [58] \\
\hline
\end{tabular}




\begin{tabular}{|c|c|c|c|}
\hline $\begin{array}{l}\text { cell \& battery } \\
\text { energy storage }\end{array}$ & & & \\
\hline $\begin{array}{l}\text { Wind energy, } \\
\text { photovoltaic sys- } \\
\text { tems, battery, fuel } \\
\text { cell \& electrolyz- } \\
\text { er }\end{array}$ & Fuzzy logic controller & Improved hybrid performance & [59] \\
\hline $\begin{array}{l}\text { Wind turbine, } \\
\text { photovoltaic, } \\
\text { diesel engine, } \\
\text { fuel-cell, aqua } \\
\text { electrolyzer and } \\
\text { other energy stor- } \\
\text { age devices: bat- } \\
\text { tery, flywheel \& } \\
\text { ultra-capacitor }\end{array}$ & $\begin{array}{l}\text { Fractional order fuzzy con- } \\
\text { trol }\end{array}$ & Improved control performance & {$[60]$} \\
\hline
\end{tabular}

Fuzzy system is implemented in modeling and control of hybrid power sources based PV, fuel cell and battery storage in micro-grid systems is presented in the provision of both real and reactive power to grid network. The method is based on the fuzzy sliding control mode to control power flow by power sharing controller as the control strategy of different power sources [58]. Similarly, the power management system of stand-alone hybrid power generation is improved with fuzzy logic controller through water cycle algorithm. The hybrid power system consists of wind power, photovoltaic systems as primary energy sources, while battery, fuel cell and electrolyzer as energy storage systems. The optimization issues in this study are focused on the operation and maintenance cost and reliability system. The proposed method is compared with PSO and non-optimized fuzzy logic controller [59]. To improve the control performance, the operation of hybrid power systems is investigated with a novel fractional order fuzzy control where its parameters are tuned with PSO algorithm augmented with two chaotic maps. The proposed method is superior to the conventional PID controller in terms of system parameter variation and rate constraint nonlinearity following the operational characteristics of hybrid power generation components [60].

\section{Meta-heuristic Optimization Techniques}

The meta-heuristic methods in solving the complexity and non-linearity characteristics of hybrid power generation are attracted attention (Table 3). It is due to the urgent of finding solutions in hybrid power generation problems, such as power quality, system stability and reliability in distribution network. In this respect, the optimization method with metaheuristic optimization algorithm called whale and sine cosine methods is robust to obtain the optimal design of the system for minimizing the total annual cost and system emissions [61]. Similarly, the complexity strategy of multiobjective optimization problem for standalone hybrid power generation for remote community energy services is presented with crow search algorithm [62]. The objective functions are total net present cost, carbon gas emission and loss of power supply probability within cost-effective, clean and reliable power supply. Effectiveness of the method is compared with multi-objective PSO.

The optimal sizing and configuration of hybrid power generation are another challenge for the optimal operation. The optimal sizing and design of standalone hybrid power generation is investigated with the objective function of minimum life cycle costs within the constraints of number of batteries, photovoltaic area, swept area of wind turbines and fuel consumption of biodiesel generator. The optimization method is based on metaheuristic approach called hybrid harmony search-simulated annealing method [63]. Similarly, the optimal sizing method of hybrid power generation is performed considering the strong combination between the intermittent energy resources, the storage capacity and load demand. The metaheuristic technique is introduced for optimization problems called Firefly algorithm considering the load dissatisfaction rate criteria and the electricity cost indicator for power reliability and cost of systems [64].

Table 3. Summary of meta-heuristic approaches

\begin{tabular}{l|l|l|l|l}
\hline Hybrid Models & $\begin{array}{l}\text { Meta-heuristic ap- } \\
\text { proaches }\end{array}$ & Tasks & Objective functions \\
\hline $\begin{array}{l}\text { Wind turbines, PV } \\
\text { arrays, battery } \\
\text { banks \& gas tur- } \\
\text { bines }\end{array}$ & $\begin{array}{l}\text { whale and sine cosine } \\
\text { methods }\end{array}$ & $\begin{array}{l}\text { Optimal design of hy- } \\
\text { brid power generation }\end{array}$ & $\begin{array}{l}\text { Minimizing the total annual cost and } \\
\text { system emissions }\end{array}$ & {$[61]$} \\
$\begin{array}{l}\text { Photovoltaic sys- } \\
\text { tem-diesel genera- } \\
\text { tor }\end{array}$ & crow search algorithm & $\begin{array}{l}\text { Reduction in total net } \\
\text { present cost, carbon gas } \\
\text { emission and loss of } \\
\text { power supply probabil- } \\
\text { ity }\end{array}$ & $\begin{array}{l}\text { Cost-effective, clean and reliable } \\
\text { power supply }\end{array}$ & [62] \\
Wind, photovoltaic, \\
$\begin{array}{l}\text { biodiesel \& battery } \\
\text { systems }\end{array}$
\end{tabular}




\begin{tabular}{l|l|l|l|l}
$\begin{array}{l}\text { PV, wind power \& } \\
\text { storage devices }\end{array}$ & Firefly algorithm & $\begin{array}{l}\text { Optimal sizing and per- } \\
\text { formance }\end{array}$ & $\begin{array}{l}\text { Maximum reliability and minimum } \\
\text { cost }\end{array}$ & [64] \\
Wind-PV systems & $\begin{array}{l}\text { Biogeography Based } \\
\text { Optimization } \\
\text { Teaching-learning based } \\
\text { Optimal sizing and op- }\end{array}$ & $\begin{array}{l}\text { Minimum total cost } \\
\text { erational strategy } \\
\text { Optimal design and } \\
\text { energy management } \\
\text { wind turbine \& } \\
\text { fuel cell }\end{array}$ & [66] & Minimum total net present cost \\
\hline
\end{tabular}

An efficient heuristic method based decision support system tools is used to enable effective and efficient energy management of hybrid power generation [65]. The proposed method is able to solve the main problems of hybrid systems, such as intermittent output power in cost-effective way of renewable energy sources, unknown load demand, and volatile and uncertain conditions of power grid. For instance, the Biogeography Based Optimization (BBO) algorithm is implemented for the optimal sizing and operational strategy of hybrid photovoltaic and wind power for rural energy application [66]. The main target of optimization is to reduce the total cost within the energy availability. The proposed method has the good convergence, fast computational effort and avoiding the convergence in the local optimum points. In addition, the intelligent flower pollination algorithm based the optimal design and energy management of hybrid power generation systems is implemented to minimize the total net present cost. The reliability index for the system, for instances loss of energy expected and loss of load expected are evaluated as the technical constraints. Regarding the optimal decision variable, the proposed method has better convergence and reliability, lower cost compared with teaching-learning based optimization (TLBO), particle swarm optimization (PSO) methods [67].

\section{Future Trends with Multi-Objective Optimization Techniques}

The multi-objective optimization technique in hybrid power generation is getting popular for the solution of more than one objective function [68]. Since the objective function is sometimes contradictory, the solution has many Paretooptimal solution and requires trade-off between objectives, optimal decision variable and trends. Multi-objective optimization technique with Pareto analysis to obtain the optimal configuration has been used in thermal based hybrid power generation [69]. For instance, the capacity optimization of hybrid power generation has been improved by several optimization techniques. For instance, an improved power management strategy (I-PMS) is proposed to improve the utilization of the battery bank and avoid the loss of power supply [70]. An economic and environmental multiobjective size optimization (EEMSO) problem for HPG systems subject to constraints of battery capacity, energy supply and component size is effectively solved by a multiobjective line-up competition algorithm (MLUCA).

The reason of intensive utilization hybrid power generation is to reduce the atmosphere gas emission since the use of clean renewable energy sources. However, the optimal configuration of hybrid systems due to the power combination is difficult. There could be many factors that influence the hybrid power performance. The optimal parameters are Levelised Cost of Energy and Loss of Power Supply Probability [71]. These factors are influenced by the load demand, wind speed, global irradiance, ambient temperature and battery bank capacity that need to be identified with multiobjective optimization techniques.

For these reasons, multi-objective optimization model is proposed to determine the optimal size of stand-alone hybrid power generation with the main target is to minimize life cycle cost and carbon gas emission [72]. The constraint for this optimization model are power production by the system components, system reliability and operation stare of battery bank. In addition, multi-objective optimization based combining the techniques of mixing design of experiments, normal boundary intersection and analysis of super efficiency using data envelopment analysis are utilized for the optimal hybrid configuration [73].

\section{Acknowledgement}

This research is granted by the National Ministry of Research, Technology and Higher Education of Indonesia under Program of Scheme for Academic and Mobility Exchange (SAME) 2018.

This is an Open Access article distributed under the terms of the Creative Commons Attribution License

\section{References}

[1] R.Baños, F.Manzano-Agugliaro, F.G.Montoya, C.Gil, A.Alcayde, J.Gómez, Optimization methods applied to renewable and sustainable energy: A review, Renewable and Sustainable Energy Reviews, vol. 15, Issue 4, pp. 1753-1766, May 2011

[2] Indragandhi.V, Subramaniyaswamy.V, Logesh.R, Resources, configurations, and soft computing techniques for power management and control of PV/wind hybrid system, Renewable and Sustainable Energy Reviews, vol. 69, pp. 129-143, March 2017

[3] Dongmin Yu, Huanan Liu, Charis Bresser, Peak load management based on hybrid power generation and demand response, Energy, vol. 163, pp. 969-985, 15 November 2018

[4] Abdullah Al-Sharafi, Bekir S.Yilbas, Ahmet Z.Sahin, T.Ayar, Performance assessment of hybrid power generation systems: Eco- nomic and environmental impacts, Energy Conversion and Management, vol. 132, pp. 418-431, 15 January 2017

[5] Ioannis P.Panapakidis, Dimitrios N.Sarafianos, Minas C.Alexiadis, Comparative analysis of different grid-independent hybrid power generation systems for a residential load, Renewable and Sustainable Energy Reviews, vol. 16, Issue 1, pp. 551-563, January 2012

[6] Rajesh Kumar, Arun Agarwala, Renewable energy technology diffusion model for techno-economics feasibility, Renewable and Sustainable Energy Reviews, vol. 54, pp. 1515-1524, February 2016

[7] Shaopeng Guo, Qibin Liu, Jie Sun, Hongguang Jin, A review on the utilization of hybrid renewable energy Renewable and Sustainable Energy Reviews, vol. 91, pp. 1121-1147August 2018 
[8] P.L.Zervas, H.Sarimveis, J.A.Palyvos, N.C.G.Markatos, Modelbased optimal control of a hybrid power generation system consisting of photovoltaic arrays and fuel cells, Journal of Power Sources, vol. 181, Issue 2, pp. 327-338, 1 July 2008

[9] Abdullah Al-Sharafi, Ahmet Z.Sahin, Bekir S.Yilbas, Overall performance index for hybrid power plants, Energy Conversion and Management, vol. 100, pp. 103-116, August 2015

[10] Jiuping Xu, Fengjuan Wang, Chengwei Lv, Qian Huang, Heping Xie, Economic-environmental equilibrium based optimal scheduling strategy towards wind-solar-thermal power generation system under limited resources, Applied Energy, vol. 231, pp. 355-371, 1 December 2018

[11] Kamal Anoune, Mohsine Bouya, Abdelali Astito, Abdellatif Ben Abdellah, Sizing methods and optimization techniques for PV-wind based hybrid renewable energy system: A review, Renewable and Sustainable Energy Reviews, vol. 93, pp. 652-673, October 2018

[12]A. Rajendra Prasad, E.Natarajan, Optimization of integrated photovoltaic-wind power generation systems with battery storage, Energy, vol. 31, Issue 12, pp. 1943-1954, September 2006

[13] Wei Wu, Veni Indah Christiana, Shin-An Chen, Jenn-Jiang Hwang, Design and techno-economic optimization of a stand-alone PV (photovoltaic)/FC (fuel cell)/battery hybrid power system connected to a wastewater-to-hydrogen processor, Energy, vol. 84, pp. 462472, 1 May 2015

[14] Wei Wu, Cheng-Yi Wang, Jenn-Jiang Hwang, Scenario-oriented design of an MFC/PV/Battery based hybrid power generation system, International Journal of Electrical Power \& Energy Systems, vol. 65 , pp. $34-40$, February 2015

[15]G.Giannakoudis, A.I.Papadopoulos, P.Seferlis, S.Voutetakis, On the Systematic Design and Optimization under Uncertainty of a Hybrid Power Generation System Using Renewable Energy Sources and Hydrogen Storage, Computer Aided Chemical Engineering, vol. 28, pp. 907-912, 2010

[16]M.Iqbal, M.Azam, M.Naeem, A.S.Khwaja, A.Anpalagan, Optimization classification, algorithms and tools for renewable energy: A review, Renewable and Sustainable Energy Reviews, vol. 39, pp. 640-654, November 2014

[17]R.Baños, F.Manzano-Agugliaro, F.G.Montoya, C.Gil, A.Alcayde, J.Gómez, Optimization methods applied to renewable and sustainable energy: A review, Renewable and Sustainable Energy Reviews, vol. 15, Issue 4, pp. 1753-1766, May 2011

[18] Cheng-Liang Chen, Hui-Chu Chen, Jui-Yuan Lee, Application of a generic superstructure-based formulation to the design of windpumped-storage hybrid systems on remote islands, Energy Conversion and Management, vol. 111, pp. 339-351, 1 March 2016

[19] Yong Yang, Su Guo, Deyou Liu, Rong Li, Yinghao Chu, Operation optimization strategy for wind-concentrated solar power hybrid power generation system, Energy Conversion and Management, vol. 160 , pp. 243-250, 15 March 2018

[20]David Hernández-Torres, Alberto J.Urdaneta Urdaneta, Paulo De Oliveira-De Jesus, A hierarchical methodology for the integral net energy design of small-scale hybrid renewable energy systems, Renewable and Sustainable Energy Reviews, vol. 52, pp. 100-110, December 2015

[21] M.Alsayed, M.Cacciato, G.Scarcella, G.Scelba, Design of hybrid power generation systems based on multi criteria decision analysis, Solar Energy, vol. 105, pp. 548-560, July 2014

[22] Jiuping $\mathrm{Xu}$, Na Luo, Meihui Li, Heping Xie, A novel paradigmoriented approach towards NG-RE hybrid power generation, Energy Conversion and Management, vol. 145, pp. 220-232, 1 August 2017

[23] Amit Kumar Singh Parihar, Virendra Sethi, Rangan Banerjee, Sizing of biomass based distributed hybrid power generation systems in India, Renewable Energy, In Press, Corrected Proof, Available online 7 September 2018

[24] M.Alamir, M.A.Rahmani, D.Gualino, Generic model identification framework for thermodynamic engines for use in hybrid power stations control and simulation, Journal of Process Control, vol. 24, Issue 6, pp. 966-974, June 2014

[25] Vincentius Surya Kurnia Adi, Chuei-Tin Chang, Development of flexible designs for PVFC hybrid power systems, Renewable Energy, vol. 74, pp. 176-186, February 2015

[26] Younggy Shin, Wong Yong Koo, Tae Hyung Kim, Seunghyun Jung, Hyeonsoo Kim, Capacity design and operation planning of a hybrid PV-wind-battery-diesel power generation system in the case of Deokjeok Island, Applied Thermal Engineering, vol. 89, pp. 514-525, 5 October 2015

[27] Sunanda Sinha, S.S.Chandel, Review of recent trends in optimization techniques for solar photovoltaic-wind based hybrid energy systems, Renewable and Sustainable Energy Reviews, vol. 50, pp. 755-769, October 2015

[28]A.Yahiaoui, F.Fodhil, K.Benmansour, M.Tadjine, N.Cheggaga, Grey wolf optimizer for optimal design of hybrid renewable energy system PV-Diesel Generator-Battery: Application to the case of Djanet city of Algeria, Solar Energy, vol. 158, pp. 941-951, December 2017

[29] Kerim Karabacak, Numan Cetin, Artificial neural networks for controlling wind-PV power systems: A review, Renewable and Sustainable Energy Reviews, vol. 29, pp. 804-827, January 2014

[30]A.U.Chávez-Ramírez, V.Vallejo-Becerra, J.C.Cruz, R.Ornelas, G.Orozco, R.Muñoz-Guerrero, L.G.Arriaga, A hybrid power plant (Solar-Wind-Hydrogen) model based in artificial intelligence for a remote-housing application in Mexico, International Journal of Hydrogen Energy, vol. 38, Issue 6, pp. 2641-2655, 27 February 2013

[31] Sunanda Sinha, S.S.Chandel, Prospects of solar photovoltaicmicro-wind based hybrid power systems in western Himalayan state of Himachal Pradesh in India, Energy Conversion and Management, vol. 105, pp. 1340-1351, 15 November 2015

[32] Chih-Ming Hong, Ting-Chia Ou, Kai-Hung Lu, Development of intelligent MPPT (maximum power point tracking) control for a grid-connected hybrid power generation system, Energy, vol. 50, pp. 270-279, 1 February 2013

[33] Ho Pham Huy Anh, Implementation of supervisory controller for solar PV microgrid system using adaptive neural model, International Journal of Electrical Power \& Energy Systems, vol. 63, pp. 1023-1029, December 2014

[34]I.Ouachani, A.Rabhi, I.Yahyaoui, B.Tidhaf, T. Fernando Tadeo, Renewable Energy Management Algorithm for a Water Pumping System, Energy Procedia, vol. 111, pp. 1030-1039, March 2017

[35] M.Kalantar, S.M.Mousavi G., Dynamic behavior of a stand-alone hybrid power generation system of wind turbine, microturbine, solar array and battery storage, Applied Energy, vol. 87, Issue 10, pp. 3051-3064, October 2010

[36]Ali Shirazi, Mehdi Aminyavari, Behzad Najafi, Fabio Rinaldi, Majid Razaghi, Thermal-economic-environmental analysis and multi-objective optimization of an internal-reforming solid oxide fuel cell-gas turbine hybrid system, International Journal of Hydrogen Energy, vol. 37, Issue 24, pp. 19111-19124, December 2012

[37] Azadeh Kamjoo, Alireza Maheri, Arash M.Dizqah, Ghanim A.Putrus, Multi-objective design under uncertainties of hybrid renewable energy system using NSGA-II and chance constrained programming, International Journal of Electrical Power \& Energy Systems, vol. 74, pp. 187-194, January 2016

[38] S.M.Mousavi G., An autonomous hybrid energy system of wind/tidal/microturbine/battery storage, International Journal of Electrical Power \& Energy Systems, vol. 43, Issue 1, pp. 11441154, December 2012

[39]Barun K.Das, Yasir M.Al-Abdeli, Optimisation of stand-alone hybrid CHP systems meeting electric and heating loads, Energy Conversion and Management, vol. 153, pp. 391-408, 1 December 2017

[40]Diego Feroldi, Lucas Nieto Degliuomini, Marta Basualdo, Energy management of a hybrid system based on wind-solar power sources and bioethanol, Chemical Engineering Research and Design, vol. 91, Issue 8, pp. 1440-1455, August 2013

[41]D.Suchitra, R.Jegatheesan, T.J.Deepika, Optimal design of hybrid power generation system and its integration in the distribution network, International Journal of Electrical Power \& Energy Systems, vol. 82, pp. 136-149, November 2016

[42] Narges Ghorbani, Alibakhsh Kasaeian, Ashkan Toopshekan, Leyli Bahrami, Amin Maghami, Optimizing a hybrid wind-PV-battery system using GA-PSO and MOPSO for reducing cost and increasing reliability, Energy, vol. 154, pp. 581-591, 1 July 2018

[43] Pablo García-Triviño, Luis M.Fernández-Ramírez, Antonio J.GilMena, Francisco Llorens-Iborra, Carlos Andrés García-Vázquez, Francisco Jurado, Optimized operation combining costs, efficiency and lifetime of a hybrid renewable energy system with energy storage by battery and hydrogen in grid-connected applications, International Journal of Hydrogen Energy, vol. 41, Issue 48, pp. 2313223144, 28 December 2016

[44]Farshad Amiri, Nassim Tahouni, Marjan Azadi M. Hassan Panjeshahi, Design of a hybrid power plant integrated with a residential area, Energy, vol. 115, Part 1, pp. 746-755, 15 November 2016

[45] Najmeh Neshat, M.R. Amin-Naseri, 'Cleaner power generation through market-driven generation expansion planning: an agentbased hybrid framework of game theory and Particle Swarm Optimization', Journal of Cleaner Production, vol. 105, pp. 206-217, 15 October 2015 
[46]Kehe Wu, Huan Zhou, A multi-agent-based energy-coordination control system for grid-connected large-scale wind-photovoltaic energy storage power-generation units, Solar Energy, vol. 107, pp. 245-259, September 2014

[47]A.Guichi, A.Talha, E.M.Berkouk, S.Mekhilef, S.Gassab, A new method for intermediate power point tracking for PV generator under partially shaded conditions in hybrid system, Solar Energy, vol. 170, pp. 974-987, August 2018

[48] Mohamed A.Mohamed, Ali M.Eltamaly, Abdulrahman I.Alolah, Swarm intelligence-based optimization of grid-dependent hybrid renewable energy systems, Renewable and Sustainable Energy Reviews, vol. 77, pp. 515-524, September 2017

[49]A.Yahiaoui, K.Benmansour, M.Tadjine, Control, analysis and optimization of hybrid PV-Diesel-Battery systems for isolated rural city in Algeria, Solar Energy, vol. 137, pp. 1-10, 1 November 2016

[50] Yashwant Sawle, S.C.Gupta, Aashish Kumar Bohre, Review of hybrid renewable energy systems with comparative analysis of offgrid hybrid system, Renewable and Sustainable Energy Reviews, vol. 81, Part 2, pp. 2217-2235, January 2018

[51]A.Chatterjee, S.P.Ghoshal, V.Mukherjee, Craziness-based PSO with wavelet mutation for transient performance augmentation of thermal system connected to grid, Expert Systems with Applications, vol. 38, Issue 6, pp. 7784-7794, June 2011

[52] Nooshin Bigdeli, Optimal management of hybrid $P V /$ fuel cell/battery power system: A comparison of optimal hybrid approaches, Renewable and Sustainable Energy Reviews, vol. 42, pp. 377-393, February 2015

[53]Farag K.Abo-Elyousr, Ahmed Elnozahy, Bi-objective economic feasibility of hybrid micro-grid systems with multiple fuel options for islanded areas in Egypt, Renewable Energy, vol. 128, Part A, pp. 37-56, December 2018

[54] Amin Hajizadeh, Masoud Aliakbar Golkar, Intelligent power management strategy of hybrid distributed generation system, International Journal of Electrical Power \& Energy Systems, vol. 29, Issue 10, pp. 783-795, December 2007

[55]Kwi-Seong Jeong, Won-Yong Lee, Chang-Soo Kim, Energy management strategies of a fuel cell/battery hybrid system using fuzzy logics, Journal of Power Sources, vol. 145, Issue 2, pp. 319-326, 18 August 2005

[56] Antonio Giallanza, Mario Porretto, Gabriella Li Puma, Giuseppe Marannano, A sizing approach for stand-alone hybrid photovoltaicwind-battery systems: A Sicilian case study, Journal of Cleaner Production, vol. 199, pp. 817-830, 20 October 2018

[57] Mostafa Rezaei, Ali Mostafaeipour, Mojtaba Qolipour, RezaT avakkoli-Moghaddam, International Journal of Hydrogen Energy, vol. 43, Issue 1, pp. 100-114, 4 January 2018, Investigation of the optimal location design of a hybrid wind-solar plant: A case study.

[58] M.Mohammadi, M.Nafar,_Fuzzy sliding-mode based control (FSMC) approach of hybrid micro-grid in power distribution systems, International Journal of Electrical Power \& Energy Systems, vol. 51, pp. 232-242, October 2013

[59] Mohammad Sarvi, Isa Nasiri Avanaki, 'An optimized Fuzzy Logic Controller by Water Cycle Algorithm for power management of Stand-alone Hybrid Green Power Generation', Energy Conversion and Management, vol. 106, pp. 118-126, December 2015

[60] Indranil Pan, Saptarshi Das, 'Fractional order fuzzy control of hybrid power system with renewable generation using chaotic PSO', ISA Transactions, In Press, Corrected Proof, Available online 26 March 2015.
[61] Mostafa A.Algabalawy, Almoataz Y.Abdelaziz, Said F.Mekhamer, Shady H.E.Abdel Aleem, Considerations on optimal design of hybrid power generation systems using whale and sine cosine optimization algorithms, Journal of Electrical Systems and Information Technology, In Press, Corrected Proof, Available online 27 March 2018

[62]Zahra Movahediyan, Alireza Askarzadeh, Multi-objective optimization framework of a photovoltaic-diesel generator hybrid energy system considering operating reserve, Sustainable Cities and Society, vol. 41, pp. 1-12, August 2018

[63] Du Guangqian, Kaveh Bekhrad, Pouria Azarikhah, Akbar Maleki, A hybrid algorithm based optimization on modeling of grid independent biodiesel-based hybrid solar/wind systems, Renewable Energy, vol. 122, pp. 551-560, July 2018

[64] Abdelhamid Kaabeche, Said Diaf, Rachid Ibtiouen, Firefly-inspired algorithm for optimal sizing of renewable hybrid system considering reliability criteria, Solar Energy, vol. 155, pp. 727-738, October 2017

[65]Kuo-Hao Chang, A decision support system for planning and coordination of hybrid renewable energy systems, Decision Support Systems, vol. 64, pp. 4-13, August 2014

[66] Rajesh Kumar, R.A.Gupta, Ajay Kumar Bansal, Economic analysis and power management of a stand-alone wind/photovoltaic hybrid energy system using biogeography based optimization algorithm, Swarm and Evolutionary Computation, vol. 8, pp. 33-43, February 2013

[67] Mohammad Jafa Hadidian Moghaddam, Akhtar Kalam, Saber Arabi Nowdeh, Abdollah Ahmadi, Manoochehr Babanezhad, Sajeeb Saha, Optimal Sizing and Energy Management of Standalone Hybrid Photovoltaic/Wind System Based on Hydrogen Storage Considering LOEE and LOLE Reliability Indices Using Flower Pollination Algorithm, Renewable Energy, In Press, Accepted Manuscript, Available online 22 September 2018

[68] GP Rangaiah, Shivom Sharma, Bhargava Krishna Sreepathi, Multiobjective optimization for the design and operation of energy efficient chemical processes and power generation, Current Opinion in Chemical Engineering, vol. 10, pp. 49-62, November 2015

[69] Pavan Kumar Naraharisetti, S.Lakshminarayanan, I.A.Karimi, Design of biomass and natural gas based IGFC using multiobjective optimization, Energy, vol 73, pp. 635-652, 14 August 2014

[70]Bin Shi, Wu Wei, Yan Liexiang, Size optimization of stand-alone $\mathrm{PV} /$ wind/diesel hybrid power generation systems, Journal of the Taiwan Institute of Chemical Engineers, vol. 73, pp. 93-101, April 2017

[71]Vinay Thapar, Impact of factors influencing the performance of hybrid energy system, Solar Energy, vol. 122, pp. 1123-1137, December 2015

[72]Nitin Agarwal, Anoop Kumar, Varun, Optimization of grid independent hybrid PV-diesel-battery system for power generation in remote villages of Uttar Pradesh, India, Energy for Sustainable Development, vol. 17, Issue 3, pp. 210-219, June 2013

[73] Marcelo Nunes Fonseca, Edsonde Oliveira Pamplona, Anderson Rodrigode Queiroz, Victor Eduardode Mello Valerio, Giancarlo Aquila, Saulo Ribeiro Silva, Multi-objective optimization applied for designing hybrid power generation systems in isolated networks, Solar Energy, vol. 161, pp. 207-219, February 2018 